
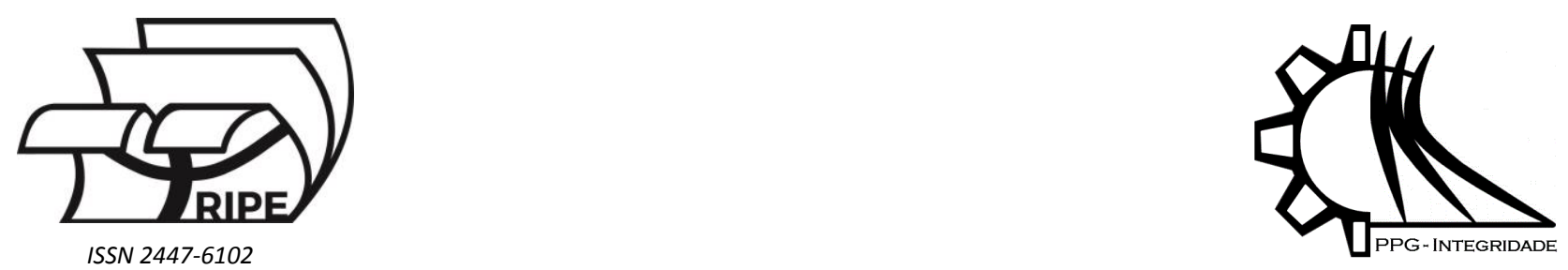

Article

\title{
Numerical study of oil spill in the Franceses Bridge region, Patos Lagoon estuary
}

\author{
Thalita Fagundes Leal ${ }^{1 *}$, Aldair Forster ${ }^{3 * *}$, Bruno Vasconcellos Lopes ${ }^{1 * * *}$, Caroline Barbosa Monteiro ${ }^{2^{+}}$, Mauren

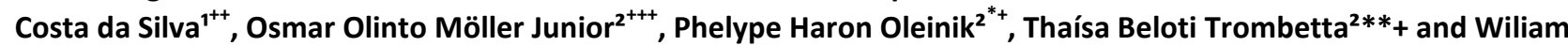 \\ Correa Marques ${ }^{1 *^{++}}$ \\ ${ }^{1}$ Programa de Pós-Graduação em Engenharia Oceânica - PPGEO, Universidade Federal do Rio Grande-FURG-Avenida Itália - \\ Carreiros, Rio Grande-RS, 96203-900, Brasil; *thalitaeinstein-fisica@hotmail.com,*** lopesbruno13@gmail.com, \\ ++mauren_costa@hotmail.com, *++wilianmarques@furg.com \\ ${ }^{2}$ Programa de Pós-Graduação em Oceanográfia Física, química e Geológica -PPG, Universidade Federal do Rio \\ Grande-FURG-Avenida Itália - Carreiros, Rio Grande-RS, 96203-900, Brasil; + monteirocbm@gmail.com, *+ \\ phe.h.01@gmail.com, +++dfsomj@furg.com,**+thaisa_bt@hotmail.com, \\ 3 Programa de Pós-Graduação em Modelagem Computacional-PPMC, Universidade Federal do Rio Grande-FURG-Avenida Itália - \\ Carreiros, Rio Grande-RS, 96203-900, Brasil; **aldairforster@gmail.com
}

Received: 14/12/2018; Accepted: 05/01/2019; Published: 07/02/2019

\begin{abstract}
The consumption pattern of the world population is based on derivatives petroleum, which despite contributing to the improvement of the quality of life, has negative aspects, mainly in the environmental scope. The number of oil spills in water slide has increased significantly in recent years. Considering the complexity of the marine environment, the present work aims to apply an identification system of the dynamics and dispersion of oil, using the numerical modeling in the region of Franceses Bridge, near to Patos Lagoon-RS, Brazil. The study of hypothetical events of oil leakage in the region is of fundamental importance, since the Riograndense Petroleum Refinery is located inside of the Patos Lagoon estuary. A data structure of atmospheric and oceanic circulation was organized and inserted in the coupling between the hydrodynamic module Telemac-3D and the ECOS oil model, during the period between 2010 and 2013. The coupling of these models gave a good approximation to the solution of the problem, besides demanding a level of computational effort propitious to obtaining results capable of giving technical and scientific support to studies such as those of environmental impacts and contingency plans.
\end{abstract}

Keywords: Numerical Modeling. Telemac-3D. ECOS.

\section{Introduction}

The oil pollution in oceans, estuaries and rivers is a large environmental problem, in its liquid state is an oily, flammable substance, less dense than water, it is considered a toxicsubstance and an accident with this substance can devastate an area and even destabilize an ecosystem.

Oil tankers and submerged oil ducts in the marine environment carry huge quantities of oil in coastal regions (Verma, 2008). According to Brekke and Solberg (2005), yearly, oil pollution in the oceans is approximately $48 \%$ caused by diesel oil and approximately $29 \%$ by crude oil.

The contamination in oceans and coastal plains is carried by a combination of the currents' phenomena: winds and waves. The oil on the surface of the sea moves between $1 \%$ and $5 \%$ of the wind speed (Elliott, 1991). Therefore, in a moderate wind (velocity of the spill $10 \mathrm{~m} \cdot \mathrm{s}^{-1}$ fluctuation velocity is approximately $0,3 \mathrm{~m} \cdot \mathrm{s}^{-1}$ (Jones, 1999).

The concern with the environment regarding oil leaks has led to the development of dynamic numerical systems, in which transport and destination of oil stains are simulated. Although more than 50 models have been developed in the last decade (Li, 2017), only a few are used extensively these days. These models help to obtain oil spill responses during and after accidents, assessing the environmental impact for the creation of a contingency plan and even planning. 
Coastal access corridors are areas at risk of pollution from oil spills, for example, due to vessel traffic and handling of fuels, necessary for economic development in these areas. The port area of Rio Grande is an example of these areas. It centralizes several petrochemical activities, such as the RPR (Refinaria Petróleo Riograndense) localized in limits of the Patos Lagoon estuary. Thus, oil spills in the region could affect both coastal activities (e.g., fishing, tourism and leisure) and the balance of the local ecosystem, which shelters environmental features vulnerable to contact with oil, such as the mangroves that surround the coastline of Patos Lagoon.

RPR's raw material, crude oil, is received through ships at the nearby oil-jetty close to the company. From oil tankers docked at the pier, the oil is conducted to the refinery by means of 10 " and 16 " oil ducts, with length of approximately $4 \mathrm{~km}$. These oil ducts receive oil at the oil tanker, pass under the Franceses Bridge and discharge into the RPR.

In this context, given the potential risks of oil spills in the Franceses Bridge region, located in the bottleneck that links the Patos Lagoon estuary to Mangueira Bay in Southern Brazil, this work has, as its contribution, the application of a deterministic model, capable of modeling hypothetical scenarios of crude oil leakage in the region

\subsection{Location and characteristics of the study}

The study region is localized in the estuarine region of Lagoa dos Patos, Fig.1, specifically in the vicinity of the Franceses Bridge, between $32^{\circ} 3^{\prime} 31^{\prime \prime} \mathrm{S}$ and $52^{\circ} 5^{\prime} 17^{\prime \prime} \mathrm{W}$, in the strait that connects Mangueira Bay to the middle Patos Lagoon estuary.

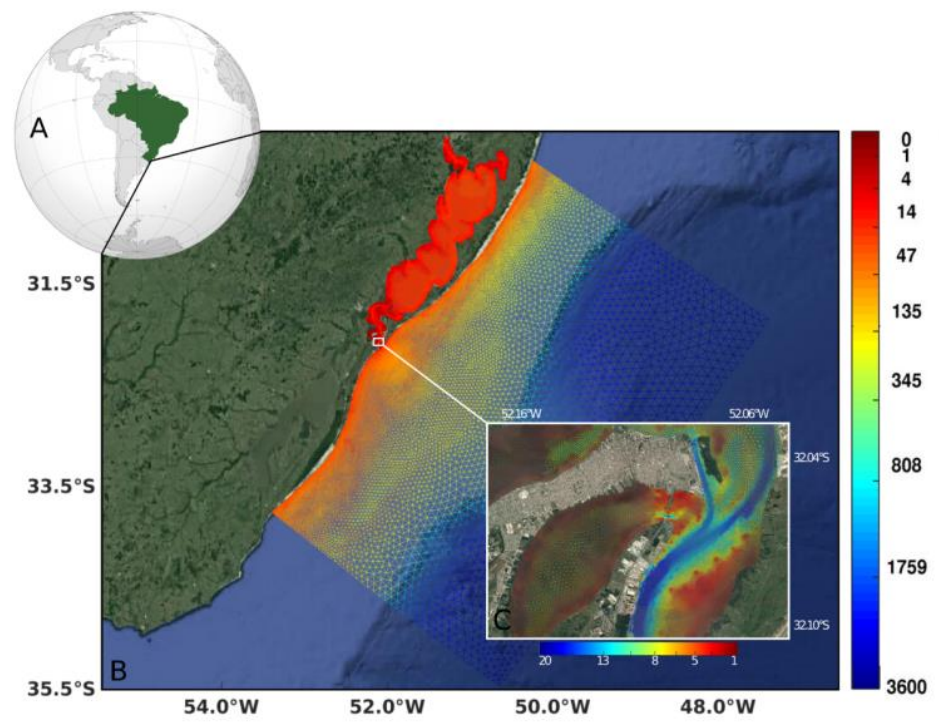

Figure 1. Study area location (A), bathymetric representation of the coastal area and the Patos Lagoon, with colors representing depth in meters (B), superimposed by Google maps, lansdsat/Copernicus, date 2018. The highlighted area is the strait that connects Mangueira Bay to the middle Patos Lagoon estuary (C), exact location of the study region.

Figure C is superimposed on Google Maps, Digital GLOBE CNES/Airbus, date 2018.

The Patos Lagoon is located in the southern region of Brazil, between $30^{\circ}-32^{\circ} \mathrm{S}$ e $50^{\circ}-52^{\circ} \mathrm{W}$, being connected to the South Atlantic Ocean through an entrance channel of $20 \mathrm{~km}$ length and $1 \mathrm{~km}$ width (Möller et al., 2005), which the estuarine portion covers $10 \%$ of the total area. The lagoon has an area of $10.360 \mathrm{~km}^{2}$ and average depth of approximately $5 \mathrm{~m}$ (Marques, 2009), therefore classified as a shallow lagoon (Calliari et al., 2009). The lagoon body topography is characterized by natural and artificial channels $(8-9 \mathrm{~m})$, large adjacent areas $(<5 \mathrm{~m})$ and shallow marginal sacks.

Möller (1996) found that the the Patos Lagoon dynamics depends essentially on Wind and freshwater discharge. The wind acting locally on the lagoon's body produces a configuration in the circulation pattern (set-up/set-down) during periods of Northeast-Southwest winds, while the longer-period oscillations generated in the region coastal áreas by remote action of the winds are attenuated as they propagate into the lagoon (Möller et al., 2002). The combination of local and remote wind action is the main mechanism that controls the introduction of salt into the estuarine region (Möller et al., 2001). 
The largest rivers (Guaíba, Camaquã and São Gonçalo) in the south of Brazil discharge their waters in this lagoon. The main contributing rivers are at the north of the lagoon and have a discharge pattern typical of temperate regions influenced by climatic processes (Marques et al., 2009). The rivers that flow into the lagoon have a total catchment área of approximately $201.626 \mathrm{~km}^{2}$, and these display a typical pattern of medium latitudes, with high discharge at the end of winter and at the beginning of spring, followed by low to moderate discharge, in the summer and autumn (Janeiro et al., 2008).

\section{METHODOLOGY}

The methodology of this work consists in the use of numerical modeling and direct analysis of the obtained results. The numerical modeling system used is Telemac, through the hydrodynamic module Telemac-3D developed within the consortium open Telemac-MASCARET. The Telemac-3D module is used for three-dimensional hydrodynamic studies of shallow water flows, as in the study region, covering the Patos Lagoon and the adjacent coastal region.

To describe the behavior of the oil in the study region, the ECOS (Easy Coupling Oil System) model developed at the Universidade Federal do Rio Grande-FURG, that has already been used in similar work on the brazilian South Continental Shelf (Mello, 2013; Marques et al., 2017).

\subsection{Computational mesh}

The computational mesh was generated by the software Blue Kenue developed by CHC (Canadian Hydraulic Centre). The triangles present variable values in the domain: $11.000 \mathrm{~m}$ in the oceanic zone, $300 \mathrm{~m}$ in Patos Lagoon and $100 \mathrm{~m}$ in the mouth of Patos Lagoon and $30 \mathrm{~m}$ in the oil spill release region, thereby the mesh has a total of 93.050 nodes.

The bathymetry data of the study region were extracted and digitized from nautical charts provided by Diretoria de Hidrografia e Navegação DNH (Diretoria de Hidrografia e Navegação). The nautical charts used were 2140 (Patos Lagoon), 2350 (Pinhal ao Rio Grande) e 2112 (Rio Grande to Chuí stream).

\subsection{Hydrodynamic model telemac-3D}

The Telemac-3D is a computational software that assists hydrodynamic studies. This model is designed to study oceans, coastal zones, estuaries and lakes. The model solves the Navier-Stokes equations considering local free surface variation and neglecting the density variation in the mass conservation equation and considering the Boussinesq approximation to solve the momentum equations, for a detailed mathematical description of the model see Hervouet (2007).

The oceanographic forcing for the hydrodynamic model is provided by the HYbrid Coordinate Ocean Model (HYCOM). The Grenoble Tide Model and the freshwater discharge are provided by the Agência Nacional de Águas (ANA). The atmospheric conditions (wind, pressure and air temperature) come from the ERA-Interim Reanalysis data sets.

\subsection{ECOS Model}

The ECOS model was developed in Laboratório de Análise Numérica e Sistemas Dinâmicos-LANSD, and has register in Instituto Nacional da Propriedade Industrial- INPI16 number 51201300013.

The ECOS is a numerical model that describes the behavior of the oil particles as discrete, using the Lagrangean approximation to evaluate the properties over time. The simulation was performed using 40.000 particles and the oil displacement is evaluated considering an inhomogeneous oil smudge. On the other hand, weathering properties are calculated using a homogeneous condition for their distribution of properties.

The simulations are performed so that the oil particles move independently through the water column. The particle velocities are interpolated at each node of the hydrodynamic numerical domain. The final position of the oil particles are dependents on the velocities of currents and wind, and the turbulent spreading and diffusion effects of the oil particles.

After the volume of oil is released into the water column, changes in its original composition occur due to a series of combinations, such as: physical-chemical processes, solar radiation, variations in ambient and water temperature, wind intensity, waves and currents. These changes in the composition of the oil are called weathering and the understanding of these processes defines the oil behavior. 
For a detailed mathematical description of the concepts used to support the development of the ECOS model, see Marques et al. (2017).

\subsection{Initial and boundary conditions}

The initial and boundary conditions are necessary to solve the hydrodynamic equations of Telemac-3D. The data were extracted from different sources for the domain of the model, then interpolated and prescribed, for each point of the finite element mesh. The model was executed for a 2 years (2010 and 2011) simulation, and was initialized from rest.

The ECOS model considers the oil spill punctual and assumes a circular geometry when spilled in the water. The initial area is calculated according to Fay (1969) and the initial spreading phase is fast.

The oil information used in the ECOS model was obtained in the technical report from Autoridade Ambiental do Rio Grande do Sul-FEPAM, Ministério do Meio Ambiente- MMA, Marinha do Brasil and Agência Nacional do Petróleo (ANP). The characteristics of the oil are presented in the Tab. 1.

Table 1. Characteristics of the oil used in the numerical simulations.

\begin{tabular}{ll}
\hline Oil Type & Marine Fuel 380 (MF-380) \\
\hline Oil Initial Volume & $13 \mathrm{~m}^{3}$ \\
\hline Sea Water Density & $1025 \mathrm{kgm}^{-3}$ \\
\hline Oil Density & $980 \mathrm{kgm}^{-3}$ \\
\hline 'API & 28 \\
\hline Saltwater Viscosity & $0,893.10^{-3} \mathrm{~m}^{2} \mathrm{~S}$ \\
\hline Particle Volume & $0,05 \mathrm{~m}^{3}$ \\
\hline
\end{tabular}

The Telemac-3D has three types of contour conditions: river discharge, ocean and solid contours. The contours of fluvial discharge come from the tributaries of the Patos Lagoon, Guaíba River, Camaquã River and the São Gonçalo channel. The ocean contours account for astronomical tide data, current velocities, salinity, and seawater temperature.

\section{Validation of hydrodynamic results}

The model hydrodynamic validation is where the abilities to reproduce the real phenomena are investigated. The Telemac-3D model was validated for the investigation of hydrodynamic processes as performed in the studies of Marques et al. (2011) and Marques et al. (2017). In the current study, a similar parameterization was used to perform the validation of three-dimensional numerical simulations.

The hydrodynamic simulation used to verify the quality of the results was conducted for the period of 2 years, between the period $01 / 01 / 2010$ and $12 / 31 / 2011$. This information was used to validate the results of the model, through the comparison with the measures of time series observed in the field. In this case, the hydrodynamic result of the simulation was compared with the observations of current velocities measured in the access channel to Patos Lagoon, at Praticagem Station, from 06/01/2011 to 30/01/2011. 
The current data were obtained with a Acoustic Doppler Current Profiler-ADCP positioned in the navigation channel (Fig.2) at a depth of $12 \mathrm{~m}$. To improve the comparison between time series, a Lanczos cosine filter was used to remove the high frequency oscillations (periods less than $12 \mathrm{~h}$ ) of the time series.

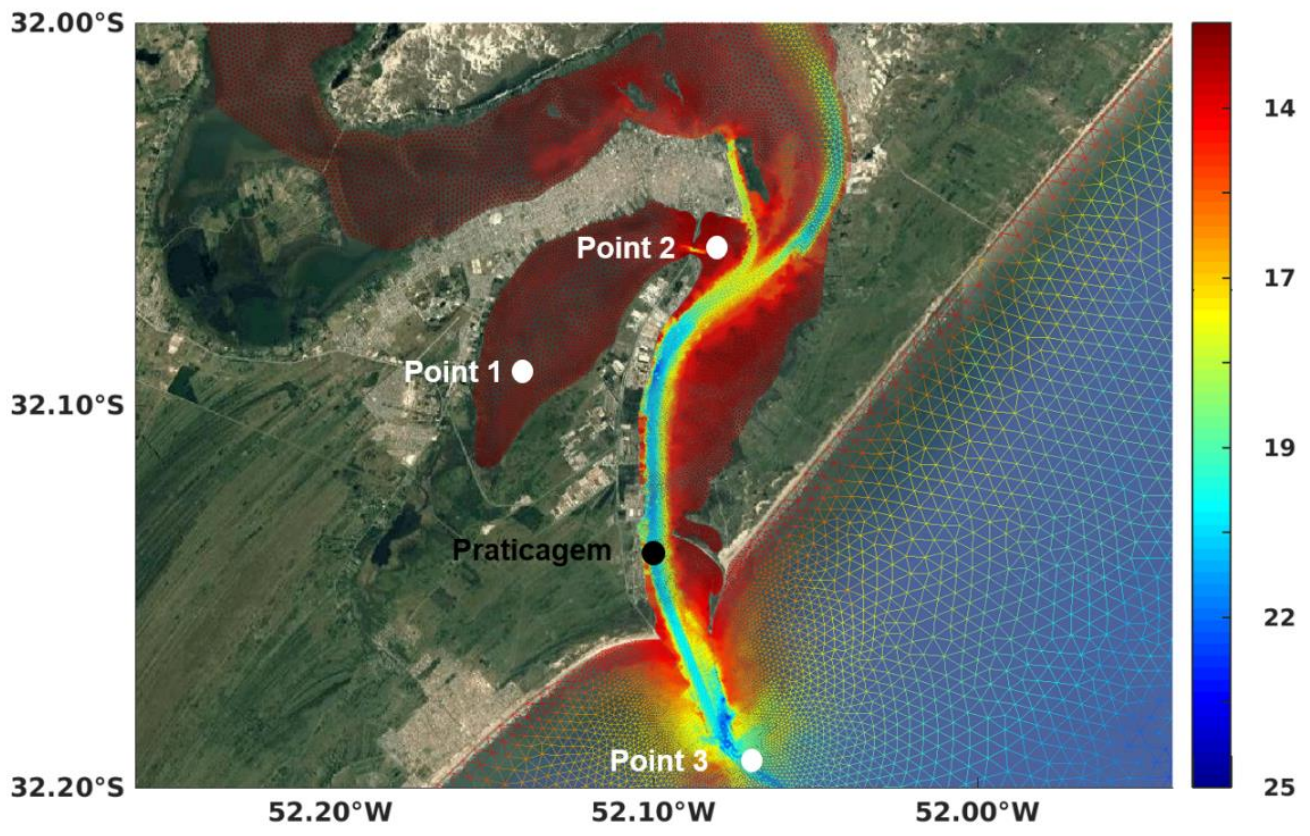

Figure 2. Equipment Position: The black dot indicates the ADCP position in the Patos Lagoon access channel, at the coordinates $32^{\circ} 8^{\prime} 12^{\prime \prime} \mathrm{S}$ and $52^{\circ} 6^{\prime} 9^{\prime \prime} \mathrm{W}$. White points 1,2 and 3 indicate where the time series of elevation were extracted.

The Fig. 3 presents the comparison between the time series with observed data (D.O) and the calculated data (D.C), obtained through numerical simulation. The performance of the simulations was quantified by the same method used by Marques et al. (2011) and Marques et al. (2017).

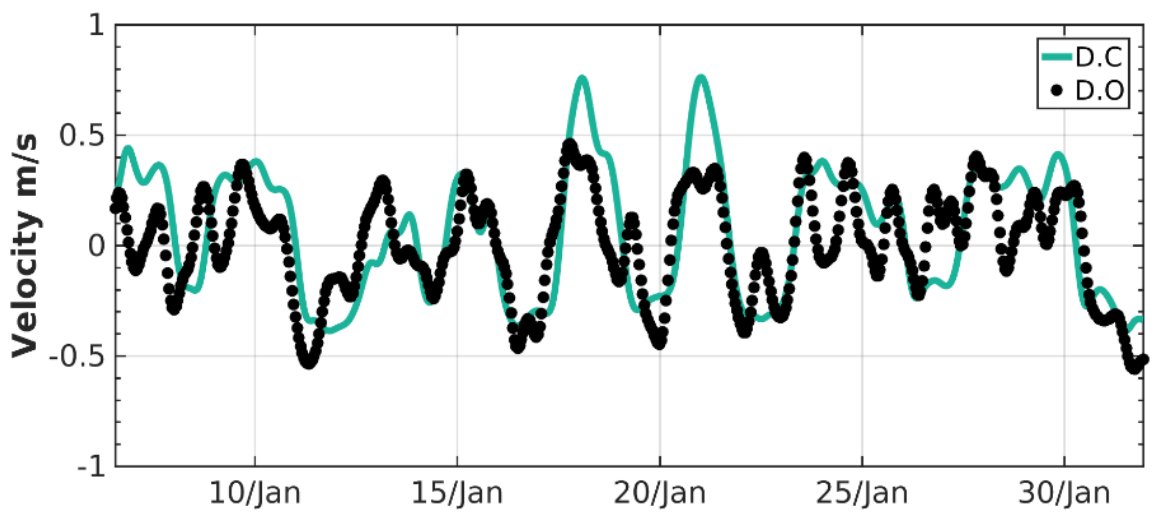

Figure 3. Southern Speed. In black, the observed data (D.O) are represented, and in green, the data calculated by the model (D.C) are presented.

The comparison between the time series of calculated current velocity indicates that the model can reproduce the velocity signal trends in the Patos Lagoon channel. The main differences, as shown in Fig. 3, appear in the period from 12 to 14 in January and also the period in january, 17 to 22, where the calculated data are underestimated with respect to the observed data. 
According to Marques et al. (2017) the underestimation of the calculated time series may be related to the use of a constant wind spacial influence coefficient, absence of waves generated by winds in the hydrodynamics or due to the use of data sets of low space-temporal resolution.

The evaluations of the comparisons presented use performance indicators such as those used in Marques et al. (2017) and Oleinik et al. (2017). The RMSE associated with the current velocity is $0,21 m . s^{-1}$ and the MAE for the surfasse component is $0,17 \mathrm{~m} . \mathrm{s}^{-1}$. The verification indicates that despite the limitations in the data used to force and verify the numerical model, the time series of current velocity represents the trends of the signals measured in the estuarine channel of the Patos Lagoon, as well as the results obtained by Marques et al. (2011) and Marques et al. (2017).

\section{Results}

To the understanding the region dynamics, a time serie of elevation calculated by the model was elaborated in order to indicate the periods of flood and ebb. With the conditions of flood and ebb it was possible to identify scenarios for hypothetical oil leaks.

The behavior analysis and displacement of the oil plume and the other properties of weathering are indicated. According Möller (1996) and Fernandes et al. (2002) the set-up and set-down mechanism, which combines local and non-local wind action, as well as the fluvial discharge of the main tributaries (Guaíba, Camaquã and São Gonçalo) are the most important factors that force the water exchange between Patos Lagoon and adjacent continental shelf, causing periods of flood, marked by the entrance of saline water fronts coming from the mouth of the Patos Lagoon access channel, and periods of ebb, which represent the exiting of the waters of the estuary.

The time series in the Fig. 4 were extracted from three different points. Point 1 (green line) is localized inside Mangueira Bay, Point 2 (blue line) is located in the estuary access channel, near the city of Rio Grande and Point 3 (red line) is situated in the exit of the jetties. These points are shown in Fig.2. The time series extracted in Point 1 and 2 show a strong relationship between the elevation in the bay and the elevation in the estuary, as already observed in Monteiro et al. (2006).

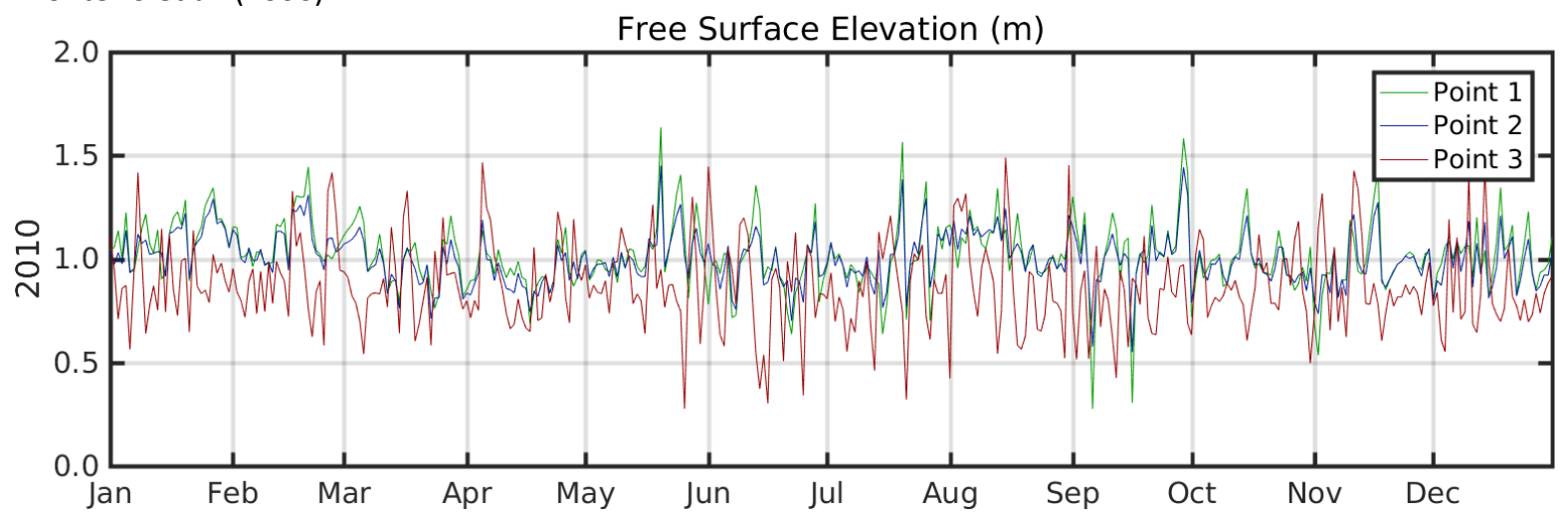

Figure 4. Elevation Time Series calculated by Telemac-3D.

Analyzing the initial period of each month (Fig.4), the months January, February, March, April, May, July, September, October and December show ebb conditions, where elevation of points 1 and 2 (green and blue line) are higher than point 3 (red line), unlike the months of June, August and November, which present a flood condition, where the elevation of point 3 (red line) is higher than point 1 and 2. This oscillation in is associated to winds and passage of frontal systems (Möller et al., 2001).

In this sense, from the results obtained in the elevation time series, a period under ebb condition was selected, highlighted in Fig.4, to simulate a hypothetical oil leak in the region of Franceses Bridge.

\subsection{Displacement of oil particles}

For the oil leak scenario, a volume of $13 \mathrm{~m}^{3}$ under the Franceses Bridge (on the water surface), where the oil ducts that transports the oil from the oil tanker until the RPR. The volume considered follows the "Modelagem e Derramamento de Óleo no Mar" standard 023/2002 of the Instituto Brasileiro do Meio Ambiente e dos RecursosNaturais Renováveis (IBAMA), which recorded the worst leakage scenario in the southern region of Brazil, with a volume of $13 \mathrm{~m}^{3}$ of oil in the Tramandaí Monoboia. 
The oil plume was tracked until its arrival in the coastal limits, during $24 \mathrm{~h}$, after the accident. Due to the lack of data to validate this model, the results are analyzed with a qualitative approach to evaluate the results.

The oil volume is dumped instantly beginning on March 1, 2010 at $12 \mathrm{~h}$. The oil particles are represented in black and the current variation intensity can be observed in the Fig.5.

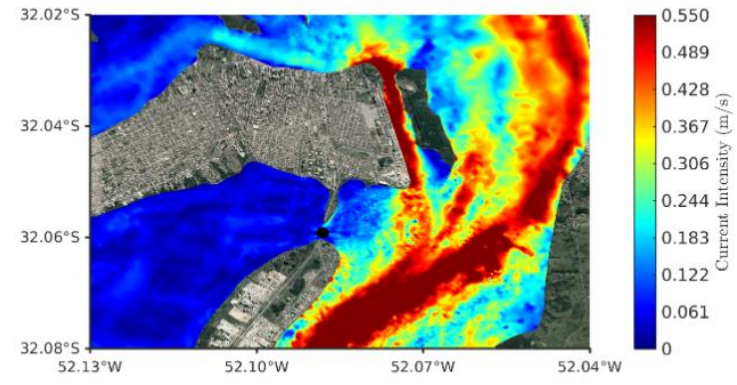

(a) Oil particles displacement after 1 hour.

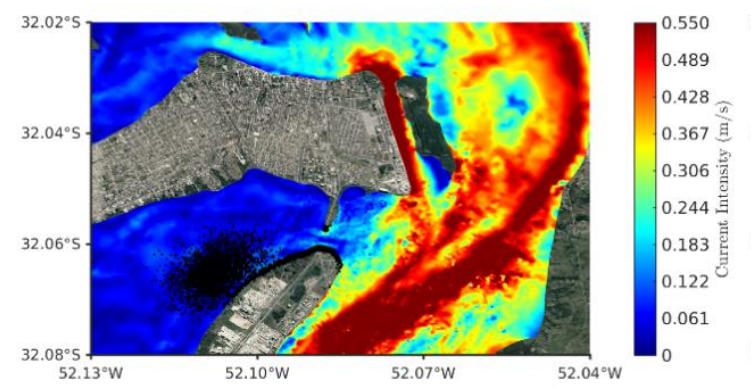

(c) Oil particles displacement after 3 hours.
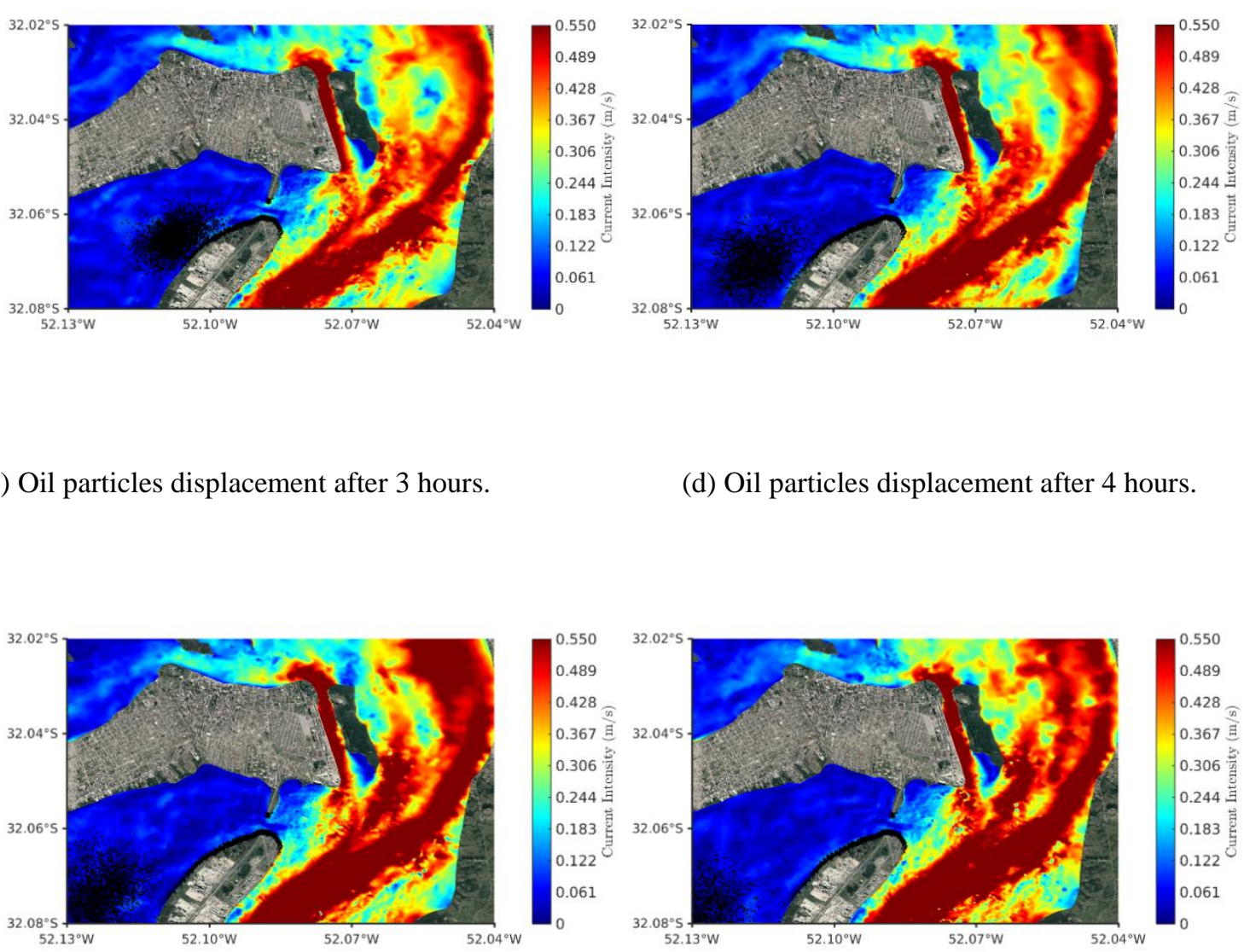

(b) Oil particles displacement after 2 hours.

(d) Oil particles displacement after 4 hours.

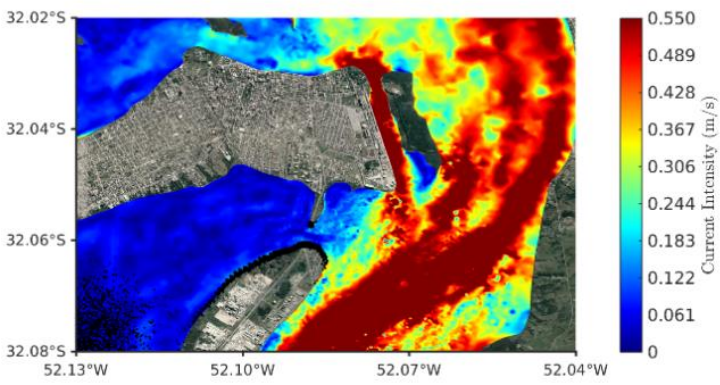

(e) Oil particles displacement after 5 hours.

(f) Oil particles displacement after 6 hours.

Figure 5. Panel showing the main points affected by oil. The oil particles are represented as black circles. 
After $6 \mathrm{~h}$ the oil plume reaches the interior of the Mangueira Bay and the coastal limits of the Rio Grande's industrial region, driven by the moderate Northeast winds of approximately $6 \mathrm{~m} . \mathrm{s}^{-1}$ (Fig.6).

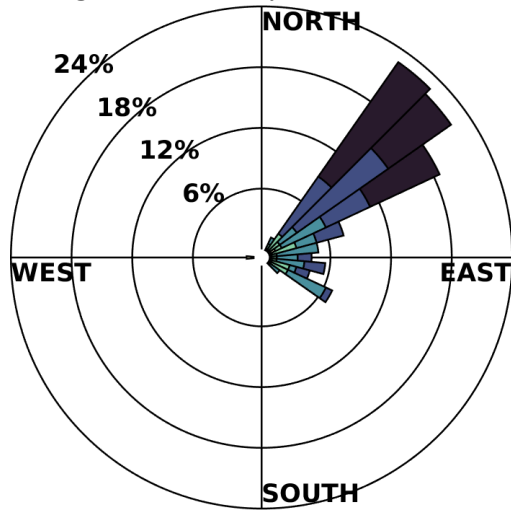

(a) Wind intensity histogram.

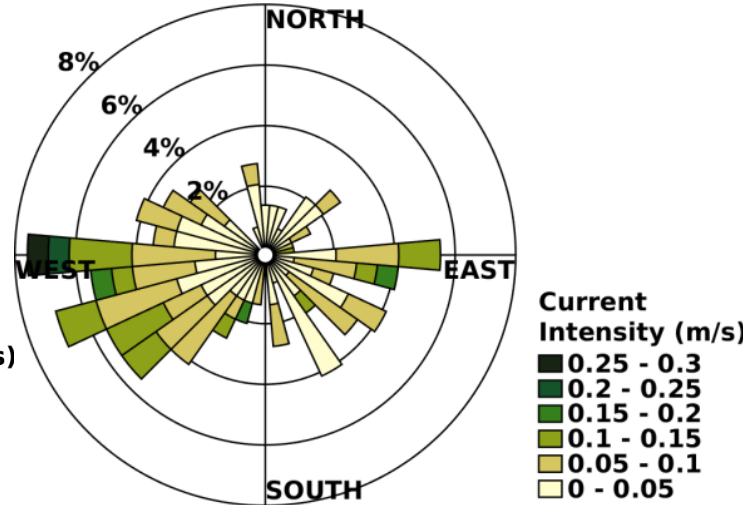

(b) Current intensity histogram.

Figure 6. Histograms of current and wind intensity.

An analysis was performed to investigate the contribution of the main physical forces that controls the behavior and destination of the oil particles. The non-dimensional contribution is obtained from the ratio of each component such as wind, currents and scattering, as well as in Marques et al. (2017).

The Fig.7 shows the individual contribution of each mechanism that contributes to the dynamics of the oil. Wind and currents play a significant role in the behavior of the oil during the simulation. During the first $6 \mathrm{~h}$, the combination of winds and currents accounts for more than $90 \%$ of the oil transport. Because it is a shallow marginal sack region the spreading is insignificant, due to the reduction of the coastal currents intensity associated with the influence of the bottom friction.

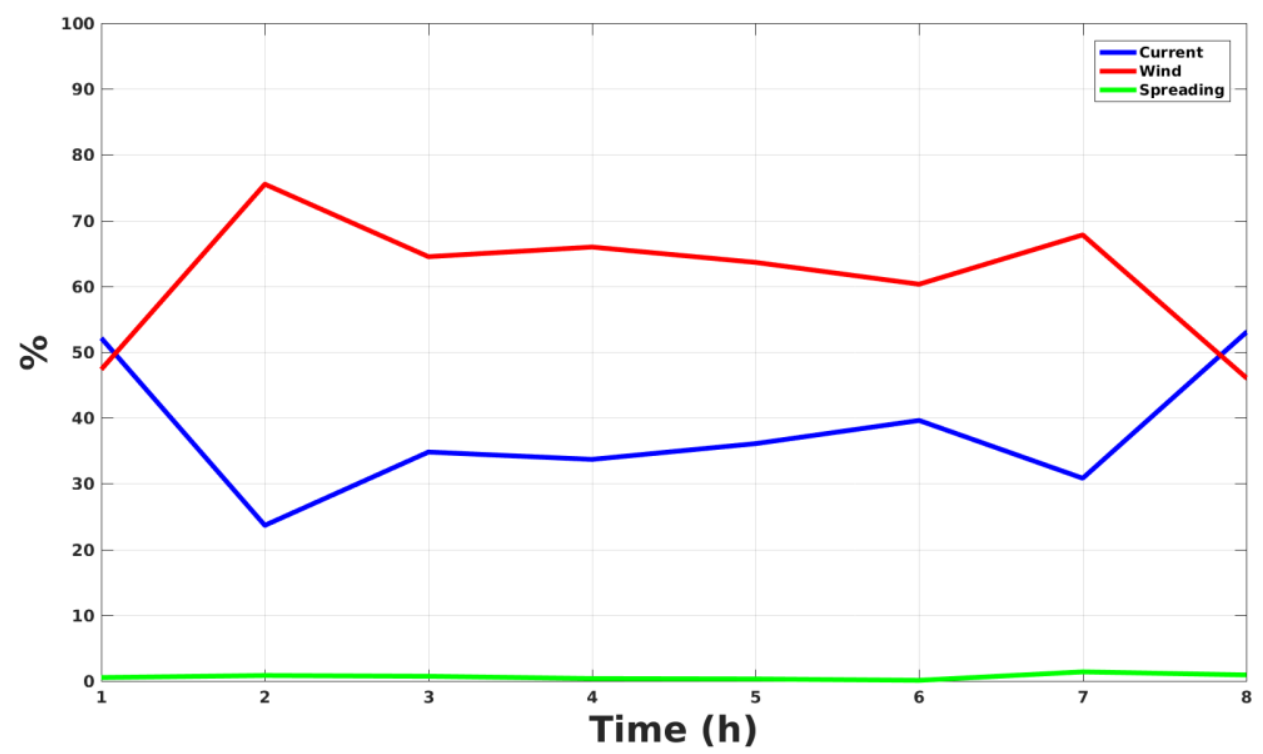

Figure 7. Individual contribution of each forcing (in percentage) during the simulated period.

Wind-induced circulation is the main factor controlling the trajectory of the oil plume, accounting for more than $65 \%$ over the simulated period. The winds control the displacement of the oil in the same way that it controls the local hydrodynamics. 


\subsection{Oil wethering}

The simulation of the trajectory of the oil particles during the leak simulation is not enough to explain the whole process that controls the displacement of the oil particles, so an analysis of the weathering was performed. The oil leakage is not homogeneous in all directions, but, as pointed in Marques et al. (2017), the oil weathering was studied considering the homogeneous properties between the particles, since the oil leak occurs on a small scale.

The Fig. 8 show the evaporation and emulsification temporal behavior. All time series were calculated using the ECOS model coupled to Telemac-3D. The maximum evaporation is $45 \%$ after $5 \mathrm{~h}$. Fingas (2012) showed that the equation used to evaluate evaporation generally overestimates the evaporation of the oil. Emulsification is highly dependent on hydrodynamic conditions of water and wind. The emulsion has a maximum water content of about $60 \%$.
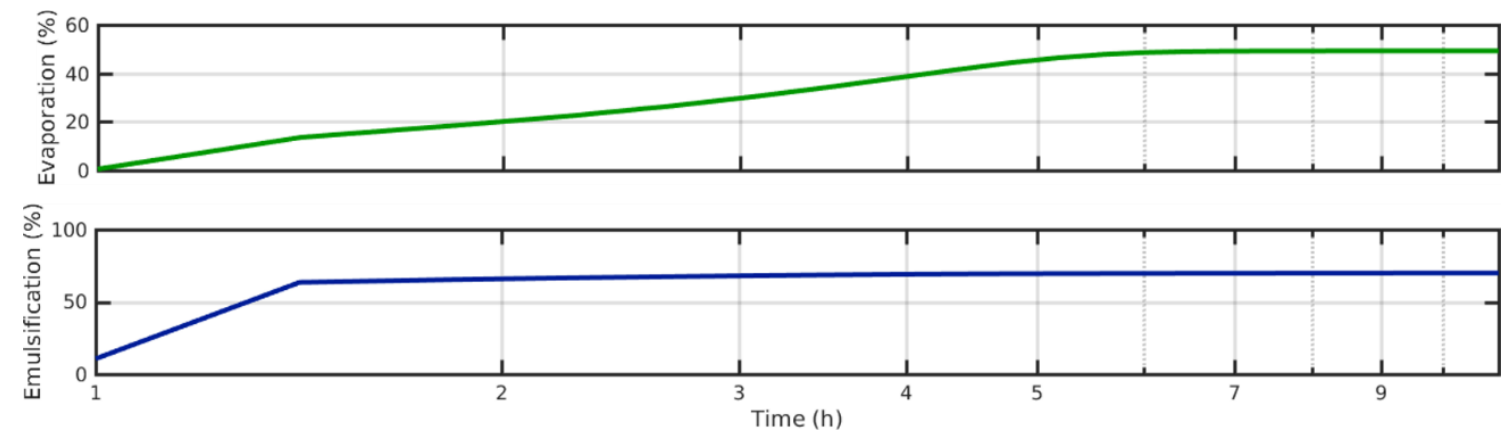

Figure 8. Oil evaporation and emulsification calculated by ECOS model Telemac-3D.

\section{Conclusions}

The behavior and destination of oil spill on March 1, 2010, in the Franceses Bridge region, was numerically investigated using an ECOS model coupled to Telemac-3D. The elaboration of a time series of elevation was presented with the purpose of presenting the conditions of ebb and flood in the region. From these conditions an ebb event, typical of the region, was selected to analyze the displacement of the oil plume influenced by the winds and currents velocity. Analysis of the oil stain behavior and the weathering properties during the simulated period were performed.

The main conclusions of this work are:

- The results of the oil displacement particles indicate that after $6 \mathrm{~h}$ the oil spill reaches the interior of the Mangueira Bay and the coastal limits of the Rio Grande industrial region, driven by winds and currents velocity representing the main physical factors that control the behavior and final destination of the oil.

- The oilweathering properties indicate $42 \%$ evaporation, the formation of an emulsion with a water content of $60 \%$.

- It will be necessary to simulate other critical oil leakage scenarios, to analyze which regions will be affected under other ebb and flood conditions.

Acknowledgment:The authors gratful for Coordenação de Aperfeiçoamento de Pessoal de Nível Superior (CAPES) for the grant of scholarships, the Conselho Nacional de Desenvolvimento Científico e Tecnológico (CNPq) by contract 304227 / 2016-1, to the Fundação de Amparo à Pesquisa do Estado do Rio Grande do Sul (FAPERGS) by contract 17 / 2551-0001 159-7 and the Centro Nacional de Supercomputação (CESUP), Universidade Federal of Rio Grande do Sul (UFRGS), which helped to develop this work. Thank you, ECMWF for the oceanographic and meteorological data boundary conditions of the model, to the Open TELEMAC-MASCARET consortium for the TELEMAC system free of charge and to the Laboratório Nacional de Computação Científica (LNCC) for the provision of use of the Santos Dumont Supercomputer.

\section{References}

1. Brekke, C., \& Solberg, A. H. (2005). Oil spill detection by satellite remote sensing. Remote sensing of environment, 95(1), 1-13.

2. Calliari, L. J., Winterwerp, J., Fernandes, E. H. L., Cuchiara, D., Vinzon, S. B., Sperle, M., \& Holland, T. (2009). Fine grain sediment transport and deposition in the Patos Lagoon-Cassino beach sedimentary system. Continental Shelf Research, 29, 515-529.

3. Elliott, A. J. (1991). EUROSPILL: Oceanographic processes and NW European shelf databases. Marine Pollution Bulletin, 22(11), 548-553. 
4. Fay, J. A. (1969). The spread of oil slicks on a calm sea. In Oil on the sea (pp. 53-63). Springer.

5. Fernandes, E. H. L., Dyer, K. R., \& Möller Jr., O. O. (2005). Spatial Gradients in the Flow of Southern Patos Lagoon. Journal of Coastal Research, 21(4), 759-769.

6. Fernandes, E. H. L., Dyer, K. R., Möller, O. O., \& Niencheski, L. F. H. (2002). The patos lagoon hydrodynamics during an el nino event (1998). Continental Shelf Research, 22(11-13), 1699-1713.

7. Fingas, M. (2012). The basics of oil spill cleanup. CRC press.

8. Hervouet, J. M. (2007). Hydrodynamics of free surface flows. Modelling with the finite element method. John Wiley \& Sons.

9. Janeiro, J., Fernandes, E. H. L., Martins, F., \& Fernandes, R. (2008). Wind and freshwater influence over hydrocarbon dispersal on Patos Lagoon, Brazil. Marine Pollution Bulletin, 56(4), 650-665.

10. Jones, B. (1999). The Use of Numerical Weather Prediction Model Output in Spill Modelling. Spill Science \& Technology Bulletin, 5(2), 153-159.

11. Li, S. (2017). Evaluation of New Weathering Algorithms (Mestrado). University Halifax.

12. Marques, W. C. (2009). Estudo da dinâmica da pluma costeira da lagoa dos patos (Unpublished doctoral dissertation). Tese de Doutorado. Universidade Federal do Rio Grande.

13. Marques, W. C., Fernandes, E. H. L., Rocha, L. A. O., \& Malcherek, A. (2011). Energy converting structures in the southern brazilian shelf: Energy conversion and its influence on the hydrodynamic and morphodynamic processes.

14. Marques, W. C., \& Möller, O. (2009). Variabilidade temporal em longo período da descarga fluvial e níveis de água da Lagoa dos Patos. Revista Brasileira de Recursos, 155-163.

15. Marques, W. C., Stringari, C. E., Kirinus, E. P., Möller Jr, O. O., \& Toldo Jr, E. E. (2017). Numerical modeling of the tramandaí beach oil spill, brazil-case study for january 2012 event. Applied Ocean Research, 65, 178-191.

16. Mello, L. F. (2013). Desenvolvimento de um Modelo de Óleo Baseado na Visão Lagrangeana de Partículas (Trabalho de Conclusão de Curso). Universidade Federal do Rio Grande.

17. Möller, O. O., Castaing, P., Salomon, J. C., \& Lazure, P. (2001). The influence of local and non-local forcing effects on the subtidal circulation of Patos Lagoon. Estuaries, 24, 297-311.

18. Monteiro, I. O., Pearsom, M., Möller, O. O., \& Fernandes, E. H. L. (2006). Hidrodinâmica do Saco da Mangueira: mecanismos que controlam as trocas com o estuário da Lagoa dos Patos. Atlântica, 27(2), 8-101.

19. Möller, O. O. (1996). Hydrodynamique de la lagune dos patos (30os, brésil): mesures et modélisation (Unpublished doctoral dissertation). Bordeaux 1.

20. Oleinik, P. H., Marques, W. C., \& Kirinus, E. P. (2017). Estimate of the Wave Climate on the Most Energetic Locations of the South-Southeastern Brazilian Shelf. Defect and Diffusion Forum, 370, 130-140.

21. Verma, A. (2008). Application of computational transport analysis: Oil spill dynamics (Master). University Libraries, New York, EUA. 